\title{
Voorwoord | Preface
}

Hierdie spesiale uitgawe van Stellenbosch Papers in Linguistics Plus is 'n uitvloeisel van die heel eerste USAN Kongres vir Jong Navorsers wat vanaf 21 tot 23 Januarie 2014 deur die Universiteit Stellenbosch (US) se Departement Afrikaans en Nederlands (AN) aangebied is. Die doel van die kongres is om 'n basis vir nagraadse studente en jong navorsers in die letterkunde, taalkunde en toegepaste taalkunde te skep om hulle navorsing, wat gebaseer is op hulle nagraadse studie, met akademiese eweknieë te deel. Jong navorsers van akademiese instellings regoor Suid-Afrika het aan die kongres deelgeneem en weens die tweetalige aard van die kongres (Afrikaans en Engels) was daar selfs internasionale verteenwoordiging uit Nieu-Seeland en België.

Following their positive conference experience and in keeping with the academic process, the young researchers (most of whom are first time authors) were offered the opportunity to submit their articles for publication in an accredited journal. SPiL Plus generously agreed to devote a special issue to articles dealing with a wide range of topics in the field of linguistics and applied linguistics (language acquisition, interpreting, translation, editing, etc.).

In die eerste artikel, wat handel oor vreemdetaalverwerwing, ondersoek Vernita Beukes en Elbie Adendorff (Universiteit Stellenbosch) die moontlikheid om 'n taakgebaseerde rekenaarprogram vir nie-Afrikaanssprekende internasionale studente aan die Universiteit Stellenbosch aan die hand van Mayer (2001) se multimedia-instruksiebeginsel te ontwerp. Die artikel poog om 'n verbinding tussen die taakgebaseerde benadering tot leer en onderrig en rekenaargesteunde taalonderrig te maak.

Joline Blignaut en Harold Lesch (Universiteit Stellenbosch) bemoei hulle in hulle artikel met 'n vraag waaroor daar tot op dese grootliks bespiegel is: Tot watter mate is die taalgebruik in die gewilde poniekoerant Son verteenwoordigend van Kaapse Afrikaans? Ten einde 'n antwoord op hierdie vraag te kry, is 'n teksanalise van Son-artikels uit verskillende uitgawes van die koerant gedoen en daar is bevind dat die taalgebruik in Son nie beskou kan word as 'n ware weerspieëling van Kaaps nie, maar eerder as informele Afrikaans wat elemente van Kaaps bevat.

Volgende raak Carmen Brewis (Universiteit Stellenbosch) 'n onderwerp aan wat toenemend belangrik is in meertalige klaskamers in Suid-Afrika: opvoedkundige tolking. Sy ondersoek een van die belangrikste kwessies waarin beleidsmakers en opvoeders belangstel, naamlik die effektiwiteit van opvoedkundige tolking vir onderrig en leer, deur die persepsies van dosente, studente en tolke ten opsigte van opvoedkundige tolking in 'n universiteitsklaskamer te toets. Tolking is oorwegend positief ervaar, maar daar is ook bevind dat opvoedkundige tolking aan sekere voorwaardes moet voldoen ten einde optimaal te kan geskied. 
Stefanie Dose (University of Johannesburg) touches on another contentious issue in interpreting, viz. the question of directionality (whether interpreters should work only from their second into their first language or whether the opposite direction is equally acceptable or even preferable). As evidence in support of both interpreting directions has been put forward, this article explores the possibility that interpreting direction may rather be influenced by extralinguistic factors (Gile 2005), and indeed demonstrates that interpreting direction is not a relevant factor in predicting interpreting performance, but appears instead to be affected by factors such as interpreters' familiarity with the topic of the speech to be interpreted.

In 'n artikel oor tweedetaalverwerwing skenk Arné Greyling en Elbie Adendorff (Universiteit Stellenbosch) aandag aan die onderrig van Afrikaans vir spesifieke doeleindes aan volwassenes op universiteitsvlak. Die artikel lewer verslag van 'n ondersoek na die spesifieke behoeftes van eerstejaar-onderwysstudente met Afrikaans as tweede taal met die doel om 'n taakgebaseerde Afrikaans vir spesifieke doeleindes-kursus te ontwerp. 'n Reeks metodologiese stappe wat in 'n behoefte-analise gevolg kan word met die oog op kursusontwerp, asook die toepassing daarvan, word aangebied.

In the first of three articles in this issue that deal with literary translation, Elzet Kirsten (Stellenbosch University) examines the unusual translation strategy of "re-tracing" (Odendaal 2011) that Breyten Breytenbach used to produce his bilingual collection of poems Oorblyfsel/ Voice Over (2009). Three concepts from literary theory, the 'contact zone' (Pratt 1987, 1992), the 'in-between' (Bhabha 1993) and the 'remainder' (Lecercle 1990), are discussed as tools which can be used to understand this strategy. The paper concludes with an analysis of two versions of one of the poems in order to illustrate and understand the effect of Breytenbach's strategy on the interpretation process that this collection of poems invites the bilingual reader to take part in.

Carla-Marié Spies (Universiteit Stellenbosch) onderneem in die volgende artikel 'n empiriese studie waarin sy die bydrae van die bronteksouteur in die produksieproses van literêre vertaling bestudeer. Die produksieprosesse van drie literêre vertalings word bestudeer en teen die agtergrond van sosiologiese, vertaal- en redigeer-/revisieteorie ontleed. Die analise dui daarop dat, alhoewel die bronteksouteur die produksieagent met die meeste outoriteit en mag is en 'n belangrike rol speel in die produksieproses, die betrokkenheid van die bronteksouteur in sekere opsigte 'n nadelige invloed op die produksieproses kan uitoefen.

Die onderwerp van selfvertaling in poësie, in die besonder in die werk van Sheila Cussons, kom weer in Marius Swart (Universiteit Stellenbosch) se artikel aan bod. Die doel van die artikel is om te bepaal of Cussons, teen die agtergrond van Lefevere (1975) se beskrywing van sewe strategieë vir die vertaling van poësie, van 'n definieerbare "tipiese" vertaalstrategie of strategieë gebruik maak. Daar word bevind dat, alhoewel Cussons se vertalings met sommige van Lefevere se strategieë ooreenstem, daar sekere strategieë aangewend word wat nie onder Lefevere se raamwerk verklaar kan word nie. Ten slotte word daar 'n aantal voorstelle gemaak vir aanvullings by Levefere se model ten einde ' $n$ vollediger raamwerk vir die bestudering van vertaalde Afrikaanse poësie te ontwikkel.

Lastly, Malvin Vergie (University of South Africa) explores the role of effective language in study guides in bridging the gap between the academic culture represented by lecturers and the non-academic culture represented by students at a distance learning institution. The article 
identifies a number of linguistic criteria to which a study guide for second language speakers of English should adhere in order to be effective. Finally, these criteria are applied to critically evaluate the language use in three study guides used at a distance learning institution.

We want to thank the reviewers of all the papers submitted for their critical but constructive comments on the submissions and the authors for making the best of these comments in the editorial revision process. A special word of thanks to Kate Huddlestone, current journal manager of SPiL Plus, for her help and support in getting this issue published.

Gerda Odendaal

Universiteit Stellenbosch

Pieter Muysken

Radboud University Nijmegen and Stellenbosch University

December 2014

\section{References}

Bhabha, H.K. 1993. Culture's in between. Artforum International 32(1): 167-168, 211-212.

Breytenbach, B. 2009. Oorblyfsel/ Voice over. Cape Town/Pretoria: Human \& Rousseau.

Gile, D. 2005. Directionality in conference interpreting: A cognitive view. In R.M. Godijns and M. Hinderdael (eds.). Directionality in interpreting: The "retour" or the native? Gent: Communication and Cognition. pp. 9-26.

Lecercle, J.J. 1990. The violence of language. London: Routledge.

Lefevere, A. 1975. Translating poetry: Seven strategies and a blueprint. Amsterdam: Van Gorcum.

Mayer, R.E. 2001. Multimedia learning. New York: Cambridge University Press.

Odendaal, P. 2011. Oortekening as vertaalstrategie in Breyten Breytenbach se "Oorblyfsel/ Voice Over". LitNet Akademies 8(2): 286-308. Available online: http://www.oulitnet.co.za/ akademies_geestes/pdf/LA_8_21_odendaal.pdf (Accessed 28 April 2014).

Pratt, M.L. 1987. Linguistic utopias. In N. Fabb, D. Attridge, A. Durant and C. MacCabe (eds.). The linguistics of writing: Arguments between language and literature. Manchester: Manchester University Press. pp. 48-66.

Pratt, M.L. 1992. Imperial eyes: Travel writing and transculturation. London and New York: Routledge. 